\title{
Composition, coagulation properties, and cheesemaking potential of milk from cows undergoing extended lactations in a pasture-based dairying system
}

\author{
M. J. Auldist, ${ }^{* 1}$ C. Grainger, ${ }^{*}$ A. V. Houlihan, $†$ J. J. Mayes, $\ddagger$ and R. P. W. Williams $\ddagger$ \\ *Department of Primary Industries, Ellinbank Victoria 3821, Australia \\ †Department of Employment, Economic Development and Innovation, Hamilton Queensland 4007, Australia \\ ¥Food Science Australia, Werribee Victoria 3030, Australia
}

\begin{abstract}
Extending the lactation length of dairy cows beyond the traditional 10 mo toward lactations of up to 22 mo has attracted interest in the pasture-based seasonal dairying systems of Australia and New Zealand as a way of alleviating the need for cows to conceive during peak lactation, such as is required to maintain seasonally concentrated calving systems. Lactation lengths longer than 10 mo instead provide cows with more time to cycle and conceive after parturition and may therefore be more suitable systems for high-producing Holstein-Friesian cows. Before recommending such systems there is a need to evaluate the effects of long lactations on the suitability of milk for manufacture of high-quality dairy products. In the current experiment, the composition of milk from cows entering the second half of a 22-mo lactation was examined in detail and compared with that from cows undergoing a traditional 10-mo lactation. On 2 occasions, coagulation properties were measured using low amplitude strain oscillation rheometry, and Cheddar cheese was made in $250-\mathrm{L}$ pilot-scale vats. Results showed that milk from extended lactations had higher concentrations of fat and protein than cows undergoing 10-mo lactations under similar management conditions and at the same time of year. The ratio of casein to true protein was not affected by lactation length and neither were the proportions of individual caseins. The increase in milk solids during extended lactations translated into a more rapid rate of coagulation and ultimately a firmer curd on one of the two occasions. Milk from extended lactations yielded more cheese per $100 \mathrm{~kg}$ of milk, and there were few differences in the composition or organoleptic properties of the cheese. These data are the first to show that pasture-based dairy industries could embrace the use
\end{abstract}

Received September 14, 2009

Accepted December 20, 2009.

${ }^{1}$ Corresponding author: Martin.Auldist@dpi.vic.gov.au of extended lactations without compromising the core business of producing high-quality dairy products.

Key words: extended lactation, cheese, milk protein, coagulation

\section{INTRODUCTION}

In the pasture-based dairying industries of Australia and New Zealand, many farmers have in recent years moved away from seasonally concentrated calving patterns and toward biseasonal (split calving) systems that supply milk all year round and incorporate lactations longer than the traditional 10 mo (Dairy Australia, 2008). Such systems alleviate the need for cows to conceive during peak production when they are in negative energy balance. Biseasonal systems can also allow farmers to take advantage of higher milk prices in winter and improve monthly cash flow (Borman et al., 2004).

Recent research in Victoria (Auldist et al., 2007; Grainger et al., 2009) and New Zealand (Kolver et al., 2007) has shown that Holstein-Friesian dairy cattle managed in pasture-based systems are capable of lactating for up to $22 \mathrm{mo}$ and that the penalty in terms of annual production of milk fat and protein is small. Further, economic analyses have shown that long lactation systems can be at least as profitable as systems with seasonally concentrated calving patterns (Malcolm, 2005; Trapnell and Malcolm, 2006).

A large proportion of the milk produced in both Victoria and New Zealand is exported as long-shelf-life manufactured dairy products, including cheese (Dairy Australia, 2008). To be sold into these export markets, such products must be manufactured according to stringent quality specifications. Meeting these specifications, in turn, relies on a source of milk of suitable quality and composition (Dalgleish, 1992).

If incorporation of extended lactations into pasturebased dairying systems is to be widely recommended, it is important to determine the effect, if any, of extended lactations on milk composition and the yield and quality of dairy products. This is especially relevant given that, 
in seasonal calving systems, milk from late in a 10-mo lactation can be problematic for the manufacture of high-quality dairy products (Lucey, 1996; Auldist et al., 1998). The current experiment had the aim of examining the effects of extended lactation on milk protein composition and the yield and quality of subsequent Cheddar cheese.

\section{MATERIALS AND METHODS}

\section{Experimental Design}

The current experiment sourced milk from a "parent" experiment aimed at examining the effect of nutrition on the capacity of cows to sustain extended lactations. Full details of that experiment are provided by Grainger et al. (2009). Briefly, 3 levels of nutrition were investigated in cows managed for 22-mo lactations, and results were compared with a control herd managed for two 10-mo lactations. Control cows had a 12-mo intercalving interval and were bred at approximately 3 mo of lactation, whereas the 22-mo lactations resulted in 24-mo intercalving intervals, with cows being bred at 15 mo of lactation.

Ninety-six Friesian cows of mixed age that calved in July or August (late winter) were used in the experiment. Cows were divided into 8 groups of 12 , balanced for age, previous production, and calving date. Two herds were randomly assigned to each of 4 treatments. Each replicate group was managed as a separate herd for the duration of the experiment.

Milk yield, gross milk composition (fat, protein, and lactose), BW, BCS, feed intake, and composition were measured at regular intervals throughout the experiment (Grainger et al., 2009).

\section{Treatments}

The 4 treatment groups were as follows:

1) Control 300; this treatment was managed for seasonal production, aiming for a yield of milk fat of $220 \mathrm{~kg}$ in each of two 300-d (10-mo) lactations. This was achieved by maintaining a minimum estimated daily ME intake of $160 \mathrm{MJ} /$ cow. Cows grazed pasture and received up to $1 \mathrm{t}$ of grain/ cow per lactation (with no more than $6 \mathrm{~kg} / \mathrm{cow}$ per day) plus pasture silage or hay, or both. This treatment represented the control against which production gains or losses in the herds managed for extended lactations were compared. The control herd underwent two 10-mo lactations during the 2-yr experiment, separated by a dry period of approximately 2 mo. Control cows that failed to get pregnant were replaced in the second year.

2) Control 670; this treatment was fed in a similar fashion to the control 300 treatment, aiming for a milk fat yield of $220 \mathrm{~kg}$ over the first $10 \mathrm{mo}$. As with the control 300 treatment, the minimum estimated daily ME intake was $160 \mathrm{MJ} /$ cow, but cows received proportionately more grain because of the need to milk them during the winter. The cows were managed to achieve a 670-d (22-mo) lactation and a 24-mo intercalving interval. This treatment was used to determine the length of lactation that could be achieved using a nutritional regimen similar to that used in conventional seasonal production systems but in cows managed for long lactations.

3) High 670; this treatment was managed for an extended lactation of 22 mo. Cows were fed a diet aimed at achieving a milk fat yield of 260 $\mathrm{kg}$ over the first $10 \mathrm{mo}$, with the constraint that the diet comprised at least $50 \%$ pasture (annual average, DM basis). Minimum daily ME intake was $180 \mathrm{MJ} /$ cow. When pasture availability and quality was limiting, especially in summer and winter, the balance of the $180 \mathrm{MJ}$ was met with additional cereal grain, pasture silage, and legume hay. This treatment was used to evaluate extended lactations in systems using higher levels of supplementary inputs, either homegrown or bought in, but maintaining a pasture base such as could be applicable in Victoria.

4) Full TMR 670; this treatment was managed for an extended lactation of 22 mo by feeding cows on 100\% TMR. The TMR comprised maize silage, pasture silage, lucerne hay, straw, starch and protein cereal, and buffers and minerals, and was offered in a feedlot. Full details of the diet are provided in Grainger et al. (2009).

\section{Milk Collection}

On 2 occasions, Cheddar cheese was made from bulk milk collected from each replicate of each treatment. The first occasion was in October 2005 (spring) when the control 300 cows were in the peak of their second lactation (approximately 3 mo postpartum) and the extended lactation cows had been milking for approximately 14 to 15 mo. The second occasion was in March 2006 (autumn) when all cows were entering the last weeks of lactation (control 300 cows had been lactating for $8 \mathrm{mo}$ and extended lactation cows had been lactating for $20 \mathrm{mo}$ ). 
Each milk collection occasion occurred over $4 \mathrm{~d}$. On d 1 and 2, at least $300 \mathrm{~L}$ of milk were collected from 1 replicate of each treatment over 4 consecutive milkings and bulked into food-grade drums. Between milkings, drums were stored at $4^{\circ} \mathrm{C}$ in a coolroom. When collection was complete, the drums were transported to Food Science Australia (FSA, Werribee, Australia) for cheesemaking. On d 3 and 4, the procedure was repeated for the other replicate of each treatment.

\section{Milk Samples}

Before transport for cheesemaking, all batches of milk were sampled by ladle after thorough but gentle agitation of the whole (1 sample per replicate, for 8 samples in total per sampling occasion). Samples were then prepared or stored for subsequent analyses. These samples were tested for all of the compositional parameters and coagulation properties listed below.

Additional samples of bulk milk from each replicate of each treatment group were collected on another 7 occasions at 4- to 6 -wk intervals, commencing 6 mo before the first cheesemaking collection. These additional samples were collected from individual cows using in-line milk meters (DeLaval International, Tumba, Sweden) and bulked according to yield to form one sample per replicate. These samples were only tested for fat, $\mathrm{CP}$, true protein, $\mathrm{CN}$, whey protein, $\kappa-\mathrm{CN}, \alpha_{\mathrm{S}^{-}}$ $\mathrm{CN}, \alpha_{\mathrm{S}_{2}} \mathrm{CN}$, and $\beta-\mathrm{CN}$.

\section{SCC}

A representative sample of the daily milk was collected from each cow using in-line milk meters within $10 \mathrm{~d}$ before the collection periods. These samples were tested for SCC using a Bentley Somacount 300 automated cell counter (Bentley Instruments, Chaska, MN). Any cow with a SCC at that previous test of $>400,000$ cells $/ \mathrm{mL}$ of milk was excluded from the collection because of the known effects of SCC on milk composition and cheese manufacture (Auldist and Hubble, 1998). As a result, only 1 replicate had a bulk milk SCC $>260,000$ cells/ $\mathrm{mL}$ (the control 670 group had a bulk SCC of 353,000 at one sampling).

\section{Milk Analyses}

Fat, CP, true protein, and CN were measured using a Fourier transform infrared (FTIR) milk analysis instrument (Foss MilkoScan FT120, Hillerød, Denmark). The MilkoScan was calibrated using a range of high, medium, and low protein milks and high, medium, and low fat milks that had been analyzed using standard reference methods for total N (Standards Australia, 1991), N fractions (NPN, noncasein N; Standards Australia, 1988a) and fat concentration (Standards Australia, 1988b). Crude protein, true protein, and CN concentrations of the reference milks were calculated from these data. Whey protein concentrations were calculated from the MilkoScan data (whey protein = true protein - $\mathrm{CN}$ ).

Milk samples were analyzed using standard methods for concentrations of TS (Standards Australia, 1988c), ash (Standards Australia, 1988d), and phosphorus (Standards Australia, 1988e), and pH (Standards Australia, 1988f). Lactose concentration was determined by difference [lactose $=\mathrm{TS}-(\mathrm{CP}+$ fat + ash $)$; Australia New Zealand Food Authority, 2000]. Citrate concentrations were determined by the procedure of White and Davies (1963). Milk urea concentrations were determined by the method of Bergmeyer (1985).

Calcium and magnesium concentrations were analyzed by either atomic absorption spectroscopy or inductively coupled plasma mass spectroscopy by Food and Agriculture Laboratories of Australia (Queensland) and Symbio Alliance (Queensland).

Concentrations of individual $\mathrm{CN}$ components $(\kappa-\mathrm{CN}$, $\alpha_{\mathrm{S} 1^{-}} \mathrm{CN}, \alpha_{\mathrm{S} 2^{-}} \mathrm{CN}$, and $\left.\beta-\mathrm{CN}\right)$ were analyzed by reverse phase HPLC (Shimadzu LC-10 analytical HPLC system with a Vydac C4 300A 3- $\mu \mathrm{m}$ column and gradient elution using acetonitrile and trifluoroacetate; Shimadzu, Kyoto, Japan). Peaks were detected at $214 \mathrm{~nm}$, which provides a more sensitive detection of proteins than measurement at $280 \mathrm{~nm}$ (Webster, 1970). Duplicate injections of each sample were analyzed.

For quantitation, response coefficients $(\boldsymbol{K})$ were determined for the 4 major $\mathrm{CN}$ components. For individual proteins, $K$ can be determined by dividing the mass of protein by the peak area at $214 \mathrm{~nm}$ (Groen et al., 1994).

Commercially available $\mathrm{CN}$ fractions were not sufficiently pure for this purpose and calculation of $K$ at $214 \mathrm{~nm}$ using Sigma standards resulted in an overestimation of total $\mathrm{CN}$ in test milks compared with the MilkoScan data. It was decided to use actual milk samples as reference milks for the determination of $K$. It was considered that concentration, instead of mass, could be used to calculate $K$, if the reference milks and the test milks were prepared in the same manner.

Concentrations of the individual $\mathrm{CN}$ components were determined in a range $(\geq 20)$ of selected reference milks. These milks were analyzed by HPLC (at $280 \mathrm{~nm}$ ) and the concentrations determined using the following equation (Garvin, 1999):

$$
\text { Concentration }(\%)=(\mathrm{A} / \varepsilon) \times(\% \mathrm{C} / \mathrm{A} \varepsilon),
$$


where concentration $=$ concentration of an individual CN component; A = HPLC peak area $(280 \mathrm{~nm})$ attributed to the individual $\mathrm{CN}$ component; $\% \mathrm{C}=$ total $\mathrm{CN}$ in milk (MilkoScan data); $\mathrm{A} \varepsilon=[(\alpha$ area $/ \alpha \varepsilon)+(\beta$ area $/ \beta \varepsilon)+(\kappa$ area $/ \kappa \varepsilon)+(\gamma$ area $/ \gamma \varepsilon)]$; and $\varepsilon=$ extinction coefficient of individual CN component (Davies and Law, 1987).

The same reference milks were then analyzed by HPLC with peak detection at $214 \mathrm{~nm}$. The peaks were integrated between the same elution times selected for the integration of peaks obtained at $280 \mathrm{~nm}$. The following equation was used to determine $K$ (at $214 \mathrm{~nm}$ ) for individual CN components (Groen et al., 1994):

$K=$ concentration (determined above) $/$ peak area $214 \mathrm{~nm}$.

By analyzing the selected reference milks in this manner, a range $(\geq 20)$ of $K$ for the individual CN components was obtained. These data were analyzed to obtain the mean $K$. The mean $K$ were then used to determine the mass fraction (or relative proportion), $\mathrm{W}$, of the individual $\mathrm{CN}$ components relative to total $\mathrm{CN}$ in the test samples, by applying the following formula (Groen et al., 1994):

$$
\begin{gathered}
\mathrm{W}=[(\text { peak area } \times K) \text { for an individual } \\
\mathrm{CN} \text { component }] /[\text { sum of }(\text { peak area } \times K) \\
\text { for all CN components }] ; \\
\text { e.g., } \mathrm{W} \kappa=(\mathrm{A} \kappa \times K \kappa) /\left[\left(\mathrm{A} \alpha_{\mathrm{S} 1} \times K \alpha\right)\right. \\
\left.+\left(\mathrm{A} \alpha_{\mathrm{S} 2} \times K \alpha\right)+(\mathrm{A} \beta \times K \beta)+(\mathrm{A} \kappa \times K \kappa)\right] .
\end{gathered}
$$

The validity of the calculated $K$ was tested by determining the concentrations of the individual $\mathrm{CN}$ components in a range of milks. The total CN concentration was then calculated by addition of the individual concentrations. There was no difference between the CN concentrations determined by HPLC and the MilkoScan data.

\section{Coagulation Properties}

Rennet setting time, curd firming rate, and rennet gel strength were assessed using low amplitude strain oscillation rheometry according to the method described by Auldist et al. (2001). Analysis of milkfat globule particle size was made in a Malvern Mastersizer 2000 instrument (Malvern Instruments, Malvern, UK). Data consisting of the particle size distribution, volume mean diameter (the arithmetic volume-based average particle diameter), and the cumulative frequency distribution were obtained for each sample.

\section{Cheesemaking}

Milk Standardization. The temperature of the milk from each batch of cheesemilk was approximately $7^{\circ} \mathrm{C}$ upon arrival at the FSA pilot-scale cheesemaking facility in Werribee. Each milk was sampled for analysis of fat and protein levels using an FTIR milk analysis instrument (Lactoscope FTIR, Delta Instruments, Drachten, the Netherlands) to facilitate standardization of the cheesemilks (data not presented). The FTIR is calibrated regularly using reference milks of varying fat, true protein, and lactose levels. These results were then used to determine how much cream or skim milk was required (if any) to standardize the milk to a protein:fat ratio of approximately 0.85 to obtain a fat-in-dry matter level of approximately $52 \%$ in the finished cheese.

Part of the milk requiring standardization was then separated at $7^{\circ} \mathrm{C}$ using a milk separator (Westfalia MTA 20, GEA Westfalia Separator, Oelde, Germany) with either the cream or skim milk used for standardizing the remaining milk. The cheesemilk was pasteurized (at approximately $73^{\circ} \mathrm{C}$ for $15 \mathrm{~s}$ ) using a plate heat exchanger, cooled to approximately $32^{\circ} \mathrm{C}$, and weighed into one of four 250-L cheese vats. A sample of the cheesemilk was taken from each vat for fat and protein analysis using the FTIR to verify the standardization process (data not presented).

Starter and Rennet Addition. Thirty units of a freeze-dried mesophilic starter (strain R708, Chr. Hansen, Victoria, Australia) was added to each vat and ripened for $30 \mathrm{~min}$ at $32^{\circ} \mathrm{C}$ before addition of rennet. A fermentation-produced chymosin (Chymogen 145, Chr. Hansen) was used as the rennet and added at a rate of $29 \mathrm{~g} / 100 \mathrm{~L}$ of milk.

Cutting and Cooking. The coagulum was cut into 13-mm cubes 10 min after the curd was at the minimum firmness for cutting as assessed by the cheesemaker. The whey $\mathrm{pH}$ was recorded at this stage. The curds and whey were then stirred and heated from 32 to $38^{\circ} \mathrm{C}$ over $40 \mathrm{~min}$ and held at $38^{\circ} \mathrm{C}$ until the whey $\mathrm{pH}$ was approximately 6.35 .

Cheddaring, Milling, Salting, Pressing, and Packing. The whey was then separated from the curd and the curd cheddared to a curd $\mathrm{pH}$ of approximately 5.45. The curd was then weighed and milled into chips of approximately $10 \times 10 \times 100 \mathrm{~mm}$. Samples of milled curd were taken for moisture analysis at this stage.

The milled curd was salted at a rate of 2.40 or $2.55 \%$ (the higher rate was used on the second cheesemak- 
ing occasion because the salt-in-moisture levels in the cheeses from the first occasion were slightly lower than the optimum level of 4.8). The salted curd was mellowed for $30 \mathrm{~min}$ before being transferred into a $20-\mathrm{kg}$ rectangular cheese mold and pressed at approximately $100 \mathrm{kPa}$ overnight at $14^{\circ} \mathrm{C}$.

The cheeses were then removed from the molds and weighed before being sampled for compositional analysis of moisture, fat, protein, salt, and $\mathrm{pH}$ using standard methods of analysis. A 1:1 cheese/water slurry was used for $\mathrm{pH}$ analysis. The cheeses were then vacuum packed in barrier bags for ripening at $8^{\circ} \mathrm{C}$.

\section{Cheese Grading}

All cheeses were graded by professional cheese graders from a commercial Cheddar cheese manufacturer in Victoria (Warrnambool Cheese and Butter Factory Company Holdings Ltd., Victoria, Australia). They graded the cheese using a 100-point scale with scores limited to between 86 and 94. Cheeses scoring 93 to 94 do not have any defects and are considered choice grade. Half or full points are deducted for defects (mostly flavor), depending on the number and severity of the defects. Cheeses scoring 90 to 92.5 are considered first grade and those scoring 86 to 89.5 second grade. Cheeses below second grade are considered unfit for retail sale.

\section{Statistical Analysis}

Repeated-measures analysis (split-plot, with herd split for sampling occasion) was applied using ANOVA if the data were balanced, or REML if data were unbalanced (because of fewer sampling occasions for the control 300 group because of the dry period) in GenStat 6 (VSN International, Hemel Hempstead, UK). Residuals were examined graphically to check for normality of distribution and constant variance, by plotting residuals versus values, histograms and normal quantile plots, and the data were tested for auto-correlation.

\section{RESULTS}

\section{Milk Composition}

Milk components that were measured at approximately monthly intervals are presented in Figures 1, 2 , and 3 , or in Table 1 . Overall, there were few differences between the extended lactation groups. Most of the observed differences were related to altered milk composition in the control 300 group compared with all of the extended lactation groups. Generally, milk from cows managed for extended lactations had higher

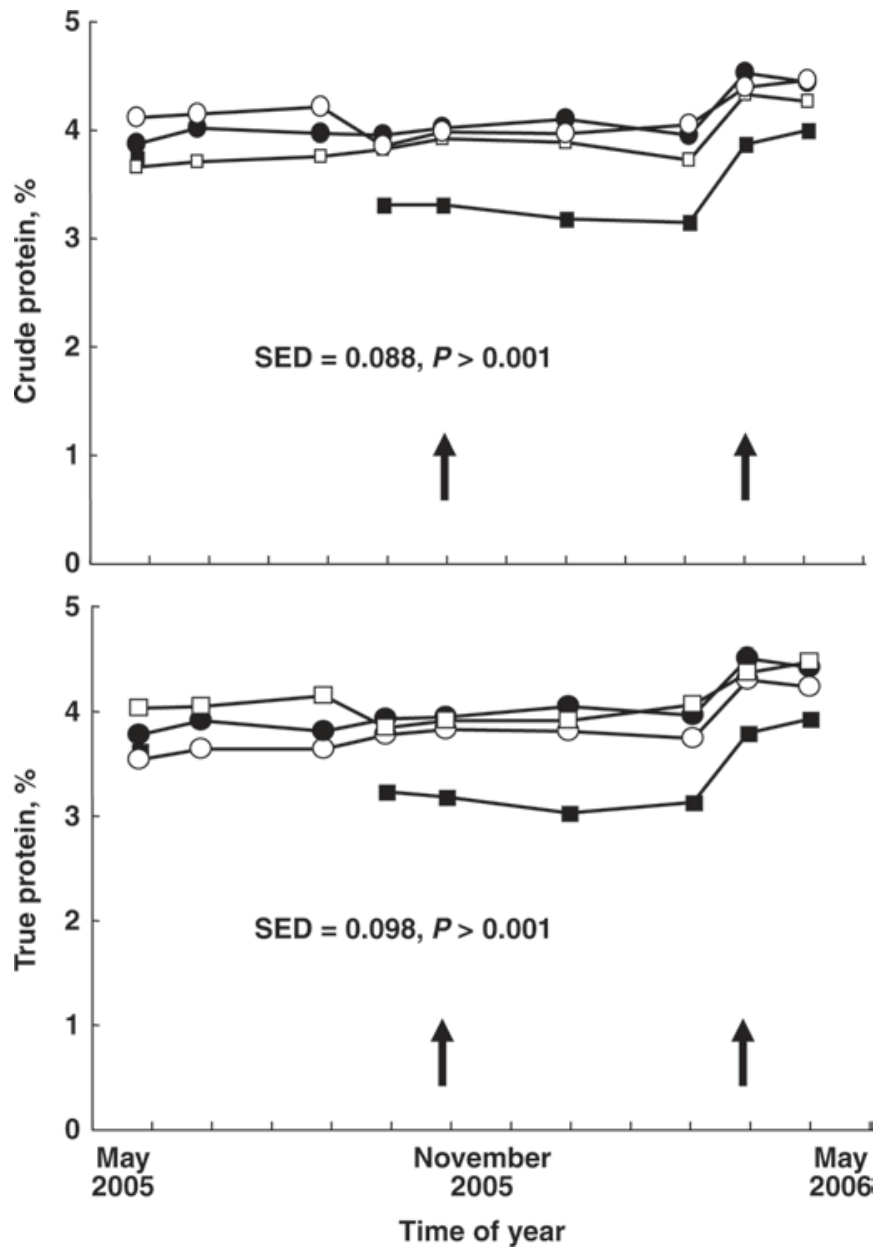

Figure 1. Concentrations of $\mathrm{CP}$ and true protein in milk from the control $300(\mathbf{\square})$, control $670(\square)$, high $670(\bullet)$, and TMR 670 (O) treatments at 4 - to 6 -wk intervals throughout the study period. Control $300=$ cows undertaking two 300-d lactations separated by a dry period of $\sim 2$ mo and fed pasture plus a moderate level of supplements; Control $670=$ same as Control 300 but cows managed for an extended lactation of $670 \mathrm{~d}$; High $670=$ cows undertaking a $670-\mathrm{d}$ lactation and fed pasture plus a high level of supplements; Full TMR 670 = cows undertaking a 670-d lactation and fed a TMR. Data are means for 2 replicates per treatment. Standard errors of differences (SED) are averages for differences between treatments. $P$-values refer to overall significance of treatment effects. Arrows indicate occasions on which cheese was made and coagulation properties measured.

concentrations of true protein, $\mathrm{CP}, \mathrm{CN}$, whey protein, and fat than milk from cows undergoing the 300-d lactation. Two of the 3 extended-lactation groups had higher proportions of both $\alpha_{\mathrm{S}_{1}} \mathrm{CN}$ and $\kappa$-CN than the control 300 group (the TMR 670 group had the highest proportion of $\kappa-\mathrm{CN})$. There were no differences in the ratio of $\mathrm{CN}$ :true protein between the groups, nor in the proportions of $\alpha_{\mathrm{S}_{2}}-\mathrm{CN}$ or $\beta-\mathrm{CN}$.

Other milk components that were measured only in milk destined for cheesemaking are presented in Table 2. Cows undergoing extended lactations had higher 
concentrations of total solids, ash, $\mathrm{Mg}$, and $\mathrm{P}$ than cows in the control 300 group. There were no differences in $\mathrm{pH}$ or concentrations of $\mathrm{Ca}$, citrate, or urea between groups. Differences in lactose occurred on one occasion but were inconsistent.

\section{Coagulation Properties}

Mean CN micelle size, fat globule size, rennet setting time, curd strength, and curd firming rate are presented in Table 3. Cows fed TMR had smaller CN micelles than cows in the other treatments, but there were no other consistent difference between the control 300 group and the extended lactation groups. On one occasion, 2 of the 3 extended-lactation groups had increased gel strengths and faster rates of coagulation compared with milk from cows in the control 300 group.

\section{Cheddar Cheese}

Composition, cheese yields, and recoveries of fat and protein from Cheddar cheese made from milk from cows in the 4 treatments are given in Table 4 . On both occasions, milk collected from cows undergoing extended lactations yielded more cheese per $100 \mathrm{~kg}$ of milk than that from cows in the control 300 treatment. There were few other differences in cheese composition or recoveries of fat or protein between treatments. An exception was a higher protein recovery in the control 300 treatment compared with the TMR 670 group, notwithstanding no overall effect of treatment group on this parameter (Table 4). All cheeses were graded at between 91 and 93 points and no significant texture or flavor defects were detected in any of them.

\section{DISCUSSION}

This experiment has provided the first information about the detailed composition and cheesemaking potential of milk from cows undergoing extended lactations in pasture-based dairying systems. In traditional seasonal calving systems, dairy processors have often reported difficulty in manufacturing high-quality products, particularly but not exclusively cheese, from late lactation milk (Kefford et al., 1995; Lucey, 1996; Auldist et al., 1998). This difficulty has been associated with changes in the protein composition and mineral balance of the milk and has necessitated costly storage of product, including cheese, to meet out-of-season demand. In considering the processing properties of milk from cows milked well beyond what would be considered late lactation in a seasonal herd, it was necessary to check that similar detrimental changes were not occurring.
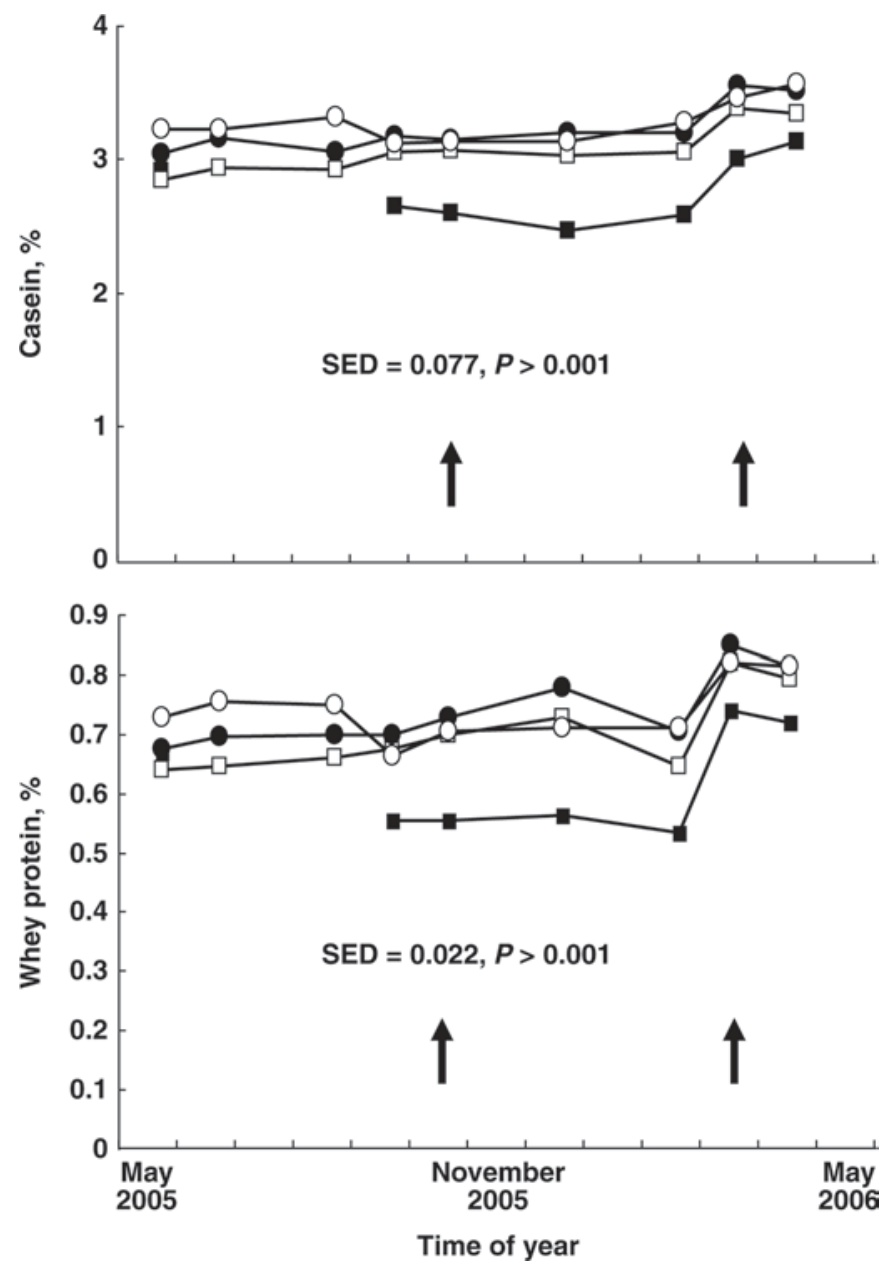

Figure 2. Concentrations of $\mathrm{CN}$ and whey protein in milk from the control $300(\square)$, control $670(\square)$, high $670(\bullet)$, and TMR $670(\bigcirc)$ treatments at 4 - to 6 -wk intervals throughout the study period. Data are means for 2 replicates per treatment. Standard errors of differences (SED) are averages for differences between treatments. $P$-values refer to overall significance of treatment effects. Arrows indicate occasions on which cheese was made and coagulation properties measured.

The results of this study showed no evidence of detrimental changes to milk processing properties during extended lactation. The only differences detected in the composition of milk from extended lactations compared with the control 300 treatment were related positively to the manufacturing potential of the milk. In particular, milk from extended-lactation cows had a higher protein concentration, and to a lesser extent fat concentration, than milk from cows undergoing normal 300-d lactations, even at the same time of year and when the level of nutrition was the same. The reason for these higher concentrations of protein in milk from extended lactations is unclear; nevertheless, the gain in milk solids counterbalances some of the reduction in milk volume that is associated with extended lacta- 
Table 1. Types of CN (\% of total CN) in milk from the 4 treatment groups ${ }^{1}$

\begin{tabular}{|c|c|c|c|c|c|c|}
\hline \multirow[b]{2}{*}{ Casein } & \multicolumn{4}{|c|}{ Treatment group ${ }^{2}$} & \multirow[b]{2}{*}{$\mathrm{SED}^{3}$} & \multirow[b]{2}{*}{$P$-value ${ }^{4}$} \\
\hline & Control 300 & Control 670 & High 670 & TMR 670 & & \\
\hline$\kappa-\mathrm{CN}$ & $9.8^{\mathrm{a}}$ & $10.7^{\mathrm{bc}}$ & $10.3^{\mathrm{ab}}$ & $11.2^{\mathrm{c}}$ & 0.30 & 0.046 \\
\hline$\alpha_{\mathrm{S}^{-}} \mathrm{CN}$ & $34.2^{\mathrm{a}}$ & $34.6^{\mathrm{a}}$ & $33.0^{\mathrm{b}}$ & $32.2^{\mathrm{b}}$ & 0.39 & 0.011 \\
\hline$\alpha_{\mathrm{S} 2}-\mathrm{CN}$ & 15.1 & 15.5 & 15.3 & 15.6 & 0.60 & 0.870 \\
\hline$\beta-\mathrm{CN}$ & 40.8 & 39.3 & 41.5 & 41.0 & 0.74 & 0.198 \\
\hline
\end{tabular}

${ }^{\mathrm{a}-\mathrm{c}}$ Means within sampling times with different superscripts are significantly different $(P<0.05)$.

${ }^{1}$ Data are means of 2 replicates per treatment at 9 sampling times. Control cows were dry at 2 of the 9 sampling times. There were no significant interactions between treatment and sampling time.

${ }^{2}$ Control 300 = cows undertaking two 300-d lactations separated by a dry period of $\sim 2$ mo and fed pasture plus a moderate level of supplements; Control $670=$ same as Control 300 but cows managed for an extended lactation of $670 \mathrm{~d}$; High $670=$ cows undertaking a 670 -d lactation and fed pasture plus a high level of supplements; Full TMR $670=$ cows undertaking a $670-d$ lactation and fed a TMR.

${ }^{3} \mathrm{SED}=$ standard error of the difference between means.

${ }^{4} P$-value refers to overall effect of treatment.

tion systems (Grainger et al., 2009). Similar increases in protein concentrations during the extended portion of lactation have been previously reported in Australia by Auldist et al. (2007) and in New Zealand by Kolver et al. (2007).

Despite the increase in milk protein during extended lactation, few differences were observed between groups in terms of the type of milk protein present. Importantly, the ratio of $\mathrm{CN}$ to true protein exhibited no consistent differences among any of the groups. This number can be an index of the manufacturing potential of milk (Auldist et al., 1998), particularly but not exclusively for cheese manufacture. The current results indicate that although there were higher levels of protein in milk from extended lactations, the protein contained similar proportions of CN. Similarly, when ratios of the individual $\mathrm{CN}$ types $\left(\kappa-\mathrm{CN}, \alpha_{\mathrm{S}^{-}} \mathrm{CN}, \alpha_{\mathrm{S} 2}-\mathrm{CN}\right.$, or $\beta-\mathrm{CN}$ ) were analyzed, no consistent differences between groups were apparent (notwithstanding that the control 300 herd had lower absolute concentrations).

No consistent differences were observed in the size of $\mathrm{CN}$ micelles or fat globules in milk from control 300 cows or cows undergoing extended lactations. Casein micelle size was smallest in the control 300 group and largest in the TMR 670 group. This finding is consistent with the observation that $\kappa-\mathrm{CN}$ proportion was lowest in the control 300 group and highest in the TMR 670 group. $\kappa$-Casein predominantly occupies the micellar surface, and increases in the proportion of $\kappa-\mathrm{CN}$ are usually accompanied by a decrease in micelle size, and vice versa, thus maintaining a similar density of $\kappa-\mathrm{CN}$ per unit surface area (O'Connell and Fox, 2000).

In contrast, we observed some differences in the way milk coagulated that were related to lactation length. In particular, on the second cheesemaking occasion, milk from the extended-lactation cows coagulated

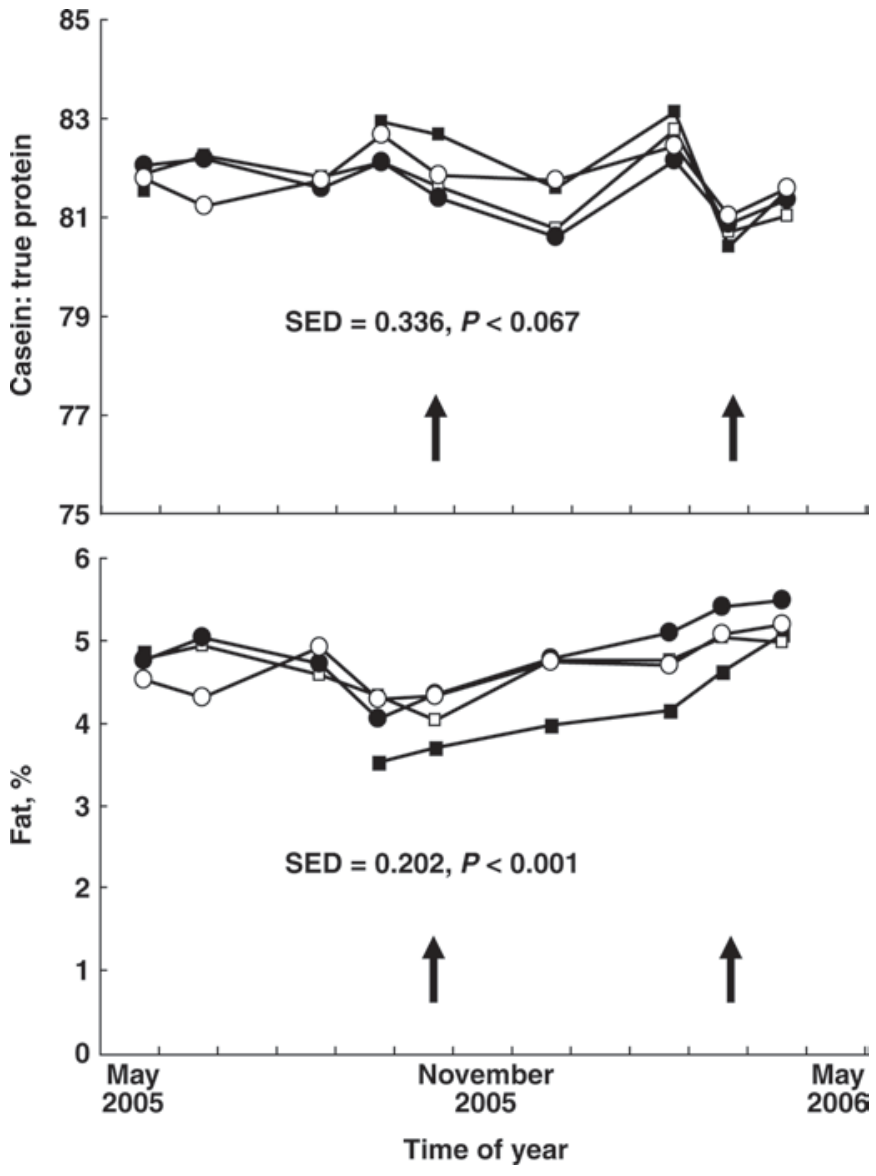

Figure 3. Ratio of casein to true protein and concentration of fat in milk from the control $300(\mathbf{\square})$, control $670(\square)$, high $670(\bullet)$, and TMR $670(\bigcirc)$ treatments at 4 - to 6 -wk intervals throughout the study period. Data are means for 2 replicates per treatment. Standard errors of differences (SED) are averages for differences between treatments. $P$-values refer to overall significance of treatment effects. Arrows indicate occasions on which cheese was made and coagulation properties measured. 
AULDIST ET AL.

Table 2. Composition of milk from cows in each of the 4 treatment groups ${ }^{1}$

\begin{tabular}{|c|c|c|c|c|c|c|c|}
\hline \multirow[b]{2}{*}{ Item } & \multirow[b]{2}{*}{ Sampling } & \multicolumn{4}{|c|}{ Treatment group ${ }^{2}$} & \multirow[b]{2}{*}{$\mathrm{SED}^{3}$} & \multirow[b]{2}{*}{$P$-value ${ }^{4}$} \\
\hline & & Control 300 & Control 670 & High 670 & TMR 670 & & \\
\hline \multirow[t]{2}{*}{ Approximate DIM } & 1 & 90 & 450 & 450 & 450 & - & - \\
\hline & 2 & 240 & 600 & 600 & 600 & - & - \\
\hline \multirow[t]{2}{*}{$\mathrm{pH}$} & 1 & 6.73 & 6.79 & 6.73 & 6.72 & 0.023 & 0.165 \\
\hline & 2 & 6.65 & 6.65 & 6.70 & 6.72 & & \\
\hline \multirow[t]{2}{*}{ Total solids, $\%$} & 1 & $12.6^{\mathrm{a}}$ & $13.4^{\mathrm{b}}$ & $13.9^{\mathrm{b}}$ & $13.7^{\mathrm{b}}$ & 0.23 & 0.005 \\
\hline & 2 & $13.9^{\mathrm{a}}$ & $14.8^{\mathrm{b}}$ & $15.5^{\mathrm{b}}$ & $15.0^{\mathrm{b}}$ & & \\
\hline \multirow[t]{2}{*}{ Ash, $\%$} & 1 & $0.74^{\mathrm{a}}$ & $0.77^{\mathrm{b}}$ & $0.77^{\mathrm{b}}$ & $0.77^{\mathrm{b}}$ & 0.008 & 0.036 \\
\hline & 2 & $0.77^{\mathrm{a}}$ & $0.80^{\mathrm{b}}$ & $0.80^{\mathrm{b}}$ & $0.80^{\mathrm{b}}$ & & \\
\hline \multirow[t]{2}{*}{ Lactose, $\%$} & 1 & $4.81^{\mathrm{a}}$ & $4.71^{\mathrm{ab}}$ & $4.76^{\mathrm{ab}}$ & $4.64^{\mathrm{b}}$ & 0.053 & 0.073 \\
\hline & 2 & 4.63 & 4.71 & 4.77 & 4.73 & & \\
\hline \multirow[t]{2}{*}{$\mathrm{Ca}, \%$} & 1 & 0.112 & 0.125 & 0.123 & 0.118 & 0.007 & 0.187 \\
\hline & 2 & 0.130 & 0.136 & 0.146 & 0.138 & & \\
\hline \multirow[t]{2}{*}{$\mathrm{Mg}, \%$} & 1 & $0.010^{\mathrm{a}}$ & $0.012^{\mathrm{b}}$ & $0.012^{\mathrm{b}}$ & $0.013^{\mathrm{b}}$ & 0.0006 & 0.006 \\
\hline & 2 & $0.010^{\mathrm{a}}$ & $0.011^{\mathrm{b}}$ & $0.012^{\mathrm{b}}$ & $0.012^{\mathrm{b}}$ & & \\
\hline \multirow[t]{2}{*}{$\mathrm{P}, \%$} & 1 & $0.092^{\mathrm{a}}$ & $0.098^{\mathrm{b}}$ & $0.100^{\mathrm{bc}}$ & $0.102^{\mathrm{c}}$ & 0.0013 & $<0.001$ \\
\hline & 2 & $0.090^{\mathrm{a}}$ & $0.097^{\mathrm{b}}$ & $0.101^{\mathrm{c}}$ & $0.103^{\mathrm{c}}$ & & \\
\hline \multirow[t]{2}{*}{ Citrate, $\%$} & 1 & 0.305 & 0.316 & 0.315 & 0.266 & 0.024 & 0.601 \\
\hline & 2 & 0.291 & 0.290 & 0.328 & 0.337 & & \\
\hline \multirow[t]{2}{*}{ Urea, \% } & 1 & 0.0255 & 0.0210 & 0.0175 & 0.0235 & 0.00654 & 0.880 \\
\hline & 2 & 0.0185 & 0.0220 & 0.0220 & 0.0250 & & \\
\hline
\end{tabular}

${ }^{a-c}$ Means within sampling times with different superscripts are significantly different $(P<0.05)$.

${ }^{1}$ Data are means of 2 replicates per treatment on each of 2 sampling occasions (October 2005 and March 2006).

${ }^{2}$ Control $300=$ cows undertaking two $300-\mathrm{d}$ lactations separated by a dry period of $\sim 2$ mo and fed pasture plus a moderate level of supplements; Control $670=$ same as Control 300 but cows managed for an extended lactation of $670 \mathrm{~d}$; High $670=$ cows undertaking a 670-d lactation and fed pasture plus a high level of supplements; Full TMR $670=$ cows undertaking a 670 -d lactation and fed a TMR.

${ }^{3} \mathrm{SED}=$ standard error of the difference between means.

${ }^{4} P$-value refers to overall effect of treatment.

Table 3. Micelle size, fat globule size, and coagulation parameters of milk from cows in the 4 treatment groups $^{1}$

\begin{tabular}{lccccccc}
\hline & & \multicolumn{7}{c}{ Treatment group $^{2}$} & \\
\cline { 3 - 6 } Item & Sampling & Control 300 & Control 670 & High 670 & TMR 670 SED $^{3}$ & $P$-value \\
\hline Approximate DIM & 1 & 90 & 450 & 450 & 450 & - & - \\
& 2 & 240 & 600 & 600 & 600 & - & - \\
Micelle size, nm & 1 & $187^{\mathrm{a}}$ & $176^{\mathrm{ab}}$ & $181^{\mathrm{a}}$ & $164^{\mathrm{b}}$ & 5.6 & 0.028 \\
& 2 & $173^{\mathrm{a}}$ & $171^{\mathrm{a}}$ & $168^{\mathrm{ab}}$ & $156^{\mathrm{b}}$ & & \\
Fat globule size, $\mu \mathrm{m}$ & 1 & 4.37 & 3.95 & 4.12 & 4.28 & 0.240 & 0.613 \\
& 2 & 3.98 & 3.99 & 4.42 & 4.19 & & \\
Rennet setting time, $\mathrm{s}$ & 1 & 1,080 & 1,072 & 1,013 & 948 & 292 & 0.994 \\
& 2 & 998 & 968 & 1,110 & 1,080 & & \\
Curd strength, Pa & 1 & 71 & 104 & 109 & 107 & 19.8 & 0.067 \\
& 2 & $119^{\mathrm{a}}$ & $170^{\mathrm{ab}}$ & $175^{\mathrm{b}}$ & $205^{\mathrm{b}}$ & & \\
Curd firming rate, $\mathrm{Pa} / \mathrm{s}$ & 1 & 38 & 58 & 64 & 65 & 11.5 & 0.048 \\
& 2 & $67^{\mathrm{a}}$ & $97^{\mathrm{ab}}$ & $101^{\mathrm{b}}$ & $122^{\mathrm{b}}$ & & \\
\hline
\end{tabular}

${ }_{\mathrm{a}, \mathrm{b}}$ Means within sampling times with different superscripts are significantly different $(P<0.05)$.

${ }^{1}$ Data are means of 2 replicates per treatment on each of 2 sampling occasions (October 2005 and March 2006).

${ }^{2}$ Control 300 = cows undertaking two 300-d lactations separated by a dry period of $\sim 2$ mo and fed pasture plus a moderate level of supplements; Control $670=$ same as Control 300 but cows managed for an extended lactation of $670 \mathrm{~d}$; High $670=$ cows undertaking a 670 -d lactation and fed pasture plus a high level of supplements; Full TMR $670=$ cows undertaking a 670 -d lactation and fed a TMR.

${ }^{3} \mathrm{SED}=$ standard error of the difference between means.

${ }^{4} P$-value refers to overall effect of treatment. 
Table 4. Composition and yield of Cheddar cheese made from milk of cows in the 4 treatment groups ${ }^{1}$

\begin{tabular}{|c|c|c|c|c|c|c|c|}
\hline \multirow[b]{2}{*}{ Item } & \multirow[b]{2}{*}{ Sampling } & \multicolumn{4}{|c|}{ Treatment group ${ }^{2}$} & \multirow[b]{2}{*}{$\mathrm{SED}^{3}$} & \multirow[b]{2}{*}{$P$-value ${ }^{4}$} \\
\hline & & Control 300 & Control 670 & High 670 & TMR 670 & & \\
\hline \multirow[t]{2}{*}{ Approximate DIM } & 1 & 90 & 450 & 450 & 450 & - & - \\
\hline & 2 & 240 & 600 & 600 & 600 & - & - \\
\hline \multirow[t]{2}{*}{ Moisture, \% } & 1 & 36.2 & 36.0 & 35.7 & 35.7 & 0.47 & 0.601 \\
\hline & 2 & 36.0 & 36.2 & 35.5 & 35.5 & & \\
\hline \multirow[t]{2}{*}{ Fat, $\%$} & 1 & 33.0 & 33.4 & 33.6 & 33.8 & 0.62 & 0.431 \\
\hline & 2 & 32.3 & 32.2 & 32.9 & 33.3 & & \\
\hline \multirow[t]{2}{*}{ Fat in the DM, \% } & 1 & 51.6 & 52.2 & 52.4 & 52.6 & 0.66 & 0.300 \\
\hline & 2 & 50.4 & 50.4 & 51.1 & 51.6 & & \\
\hline \multirow{2}{*}{ Protein, $\%$} & 1 & 26.0 & 25.7 & 25.7 & 25.5 & 0.27 & 0.193 \\
\hline & 2 & 26.1 & 25.9 & 26.1 & 25.8 & & \\
\hline \multirow[t]{2}{*}{ Salt, $\%$} & 1 & 1.62 & 1.72 & 1.69 & 1.74 & 0.05 & 0.023 \\
\hline & 2 & $1.78^{\mathrm{a}}$ & $1.94^{\mathrm{b}}$ & $1.82^{\mathrm{ab}}$ & $1.83^{\mathrm{ab}}$ & & \\
\hline \multirow[t]{2}{*}{ Salt-in-moisture, $\%$} & 1 & $4.49^{\mathrm{a}}$ & $4.77^{\mathrm{ab}}$ & $4.71^{\mathrm{ab}}$ & $4.87^{\mathrm{b}}$ & 0.113 & 0.006 \\
\hline & 2 & $4.95^{\mathrm{a}}$ & $5.35^{\mathrm{b}}$ & $5.10^{\mathrm{ab}}$ & $5.20^{\mathrm{ab}}$ & & \\
\hline \multirow[t]{2}{*}{$\mathrm{pH}$} & 1 & 5.40 & 5.41 & 5.40 & 5.43 & 0.067 & 0.546 \\
\hline & 2 & 5.44 & 5.52 & 5.50 & 5.50 & & \\
\hline \multirow[t]{2}{*}{ Cheese yield, $\mathrm{kg} / 100 \mathrm{~kg}$} & 1 & $9.89^{\mathrm{a}}$ & $11.72^{\mathrm{b}}$ & $12.07^{\mathrm{b}}$ & $11.80^{\mathrm{b}}$ & 0.373 & 0.003 \\
\hline & 2 & $11.50^{\mathrm{a}}$ & $12.81^{\mathrm{b}}$ & $13.08^{\mathrm{b}}$ & $13.11^{\mathrm{b}}$ & & \\
\hline \multirow[t]{2}{*}{ Fat recovery, $\%$} & 1 & 88.2 & 90.4 & 90.1 & 88.5 & 1.28 & 0.676 \\
\hline & 2 & 86.8 & 86.2 & 87.1 & 87.4 & & \\
\hline \multirow[t]{2}{*}{ Protein recovery, $\%$} & 1 & $81.8^{\mathrm{a}}$ & $80.8^{\mathrm{ab}}$ & $80.4^{\mathrm{ab}}$ & $79.5^{\mathrm{b}}$ & 0.512 & 0.074 \\
\hline & 2 & 82.2 & 80.8 & 80.7 & 80.6 & & \\
\hline
\end{tabular}

${ }_{\mathrm{a}, \mathrm{b}}$ Means within sampling times with different superscripts are significantly different $(P<0.05)$.

${ }^{1}$ Data are means of 2 replicates per treatment on each of 2 sampling occasions (October 2005 and March 2006).

${ }^{2}$ Control $300=$ cows undertaking two 300 -d lactations separated by a dry period of $\sim 2$ mo and fed pasture plus a moderate level of supplements; Control $670=$ same as Control 300 but cows managed for an extended lactation of $670 \mathrm{~d}$; High $670=$ cows undertaking a 670 -d lactation and fed pasture plus a high level of supplements; Full TMR $670=$ cows undertaking a $670-d$ lactation and fed a TMR.

${ }^{3} \mathrm{SED}=$ standard error of the difference between means.

${ }^{4} P$-value refers to overall effect of treatment.

more quickly and ultimately formed a firmer curd than milk from control 300 cows, as assessed by rennet gel strength (measured independently of the cheesemaking process using low amplitude strain oscillation rheometry). There was a similar (nonsignificant) trend at the first cheesemaking occasion. This is almost certainly related to the higher concentrations of protein in the milk (Guinee et al., 1997). If, during cheesemaking, milk is rennet-treated on a casein basis and curd is cut based on curd firmness, higher milk protein concentrations can lead to a lower moisture content of the resultant cheese. In contrast, if the curds are cut based on time, then an increase in milk protein content is likely to coincide with an increase in the moisture content of the curd, because the stiffer gel at cutting has a lower ability to rearrange and synerese (Guinee et al., 2006). In the current study, in which curd was cut 10 min after acceptable curd firmness had been reached, there were no differences in cheese moisture contents. This is possibly because the rennet was added on a volume basis $(\mathrm{mL} / 100 \mathrm{~kg}$ of milk) rather than on a casein load basis
$(\mathrm{mL} / \mathrm{kg}$ of casein). It is also of note that commercial cheesemakers often cut the curd at a predetermined time after rennet addition rather than based on gel firmness, and consequently report a firmer gel at cut but a higher cheese moisture content in cheese made from higher protein milk (T. Guinee, Moorepark Food Research Centre, Teagasc Food Research, Ireland; personal communication).

Besides some minor differences in salt and salt-inmoisture concentrations, there was no effect of treatment on cheese composition. All parameters, including cheese moisture concentrations, would have been within industry specifications.

There was, however, a substantial difference in cheese yields between the control 300 treatments and the extended lactation treatments. Compared with control 300 cows, for example, control 670 cows yielded almost $1.9 \mathrm{~kg}$ more cheese per $100 \mathrm{~kg}$ of milk, an increase of $18.5 \%$. The other extended-lactation milks had similarly enhanced cheese yields. This was mostly because of the increased concentrations of $\mathrm{CN}$ and fat even 
after standardizing the milk for cheesemaking, because primarily $\mathrm{CN}$ and fat are incorporated into the curd during cheesemaking.

All cheeses graded between 91 and 93 points and none displayed any significant texture or flavor defects of any kind. This is a positive result in that it shows that the gains in cheese yields from extended-lactation milks did not come at the expense of cheese quality.

The current experiment also generated data regarding the effects of level of feeding on milk composition and manufacturing properties. There were, however, few differences in milk composition, coagulation properties, or cheese yield and composition associated with the different diets. Consequently, this paper has focused on the differences due to targeted lactation length (10 vs. $22 \mathrm{mo}$ ).

In summary, this experiment has provided no evidence that extending lactation has any deleterious effects on the composition or cheesemaking properties of milk. On the contrary, milk from extended lactations was seen to have higher concentrations of solids (mostly protein but also fat). This translated into superior coagulation properties and ultimately into higher cheese yields per $100 \mathrm{~kg}$ of milk. This increase in cheese yield was not associated with any compromise in cheese quality: professional cheese graders agreed that cheese quality was the same for all groups. These data should provide the dairy industry with some confidence that extended lactations can be employed in pasture-based dairying systems without compromising the quality of subsequent cheese.

\section{ACKNOWLEDGMENTS}

The milk analyses and cheesemaking components of this study were funded by Dairy Australia and the Queensland Department of Primary Industries and Fisheries (Hamilton, Queensland, Australia). The wider experiment (Grainger et al., 2009) was funded by the Victorian Department of Primary Industries, the Geoffrey Gardiner Dairy Foundation, Keenan, University of Melbourne, and the National Herd Improvement Association. The authors are grateful to R. Case, D. Mapleson, and T. Hookey (DPI Ellinbank, Victoria, Australia) for technical expertise and animal husbandry, N. Spiller, A. Cusack, and J. Graf (Queensland Department of Primary Industries and Fisheries) for milk analyses, and M. Hannah (DPI Ellinbank) for statistical analyses.

\section{REFERENCES}

Auldist, M., C. Mullins, B. O'Brien, and T. Guinee. 2001. A comparison of the Formagraph and low amplitude strain oscillation rheometry as methods for assessing the rennet coagulation properties of bovine milk. Milchwissenschaft 56:89-92.

Auldist, M. J., and I. B. Hubble. 1998. Effects of mastitis on raw milk and dairy products. Aust. J. Dairy Technol. 53:28-36.

Auldist, M. J., G. O'Brien, D. Cole, K. L. Macmillan, and C. Grainger. 2007. Effects of varying lactation length on milk production capacity of cows in pasture-based dairying systems. J. Dairy Sci. 90:3234-3241.

Auldist, M. J., B. J. Walsh, and N. A. Thomson. 1998. Seasonal and lactational influences on bovine milk composition in New Zealand. J. Dairy Res. 65:401-411.

Australia New Zealand Food Authority. 2000. Amendment No. 53 to the Food Standards Code. Commonwealth of Australia Gazette No. P 30, Dec 20, 2000.

Bergmeyer, H. U. 1985. Urea colourimetric method. Pages 449-453 in Methods of Enzymatic Analysis. Vol VIII Metabolites. 3. Lipids, Amino Acids and Related Compounds, 3rd ed. H. U. Bergmeyer, ed. Verlag Chemie, Weinheim, Germany.

Borman, J. M., K. L. Macmillan, and J. Fahey. 2004. The potential for extended lactations in Victorian dairying: A review. Aust. J. Exp. Agric. 44:507-519.

Dairy Australia. 2008. Situation and Outlook. Online: www. dairyaustralia.com.au. Accessed May 27, 2009.

Dalgleish, D. G. 1992. Bovine milk protein properties and the manufacturing quality of milk. Livest. Prod. Sci. 35:75-93.

Davies, D. T., and A. J. R. Law. 1987. Quantitative fractionation of casein mixtures by fast protein liquid chromatography. J. Dairy Res. 54:369-376.

Garvin, J. M. 1999. Quantitative fractionation of bovine casein by fast protein liquid chromatography. Pages 263-273 in The Effect of Dietary Protein Degradability and Genetics on the Protein Quality of Milk for Cheese Manufacture. PhD Thesis. Department of Animal Science, University of Sydney, Australia.

Grainger, C., M. J. Auldist, G. O'Brien, K. L. Macmillan, and C. Culley. 2009. Effect of type of diet and energy intake on milk production of Holstein-Friesian cows with extended lactations. J. Dairy Sci. 92:1479-1492.

Groen, A. F., R. van der Vegt, M. A. J. S. van Boekel, O. L. A. M. de Rouw, and H. Vos. 1994. Case study on individual animal variation in milk protein composition as estimated by high-pressure liquid chromatography. Neth. Milk Dairy J. 48:201-212.

Guinee, T. P., C. B. Gorry, D. J. O'Callaghan, B. T. O'Kennedy, N. O'Brien, and M. A. Fenelon. 1997. The effects of composition and some processing treatments on the rennet coagulation properties of milk. Int. J. Dairy Technol. 50:99-106.

Guinee, T. P., B. T. O'Kennedy, and P. M. Kelly. 2006. Effect of standardization using different methods on the composition and yields of Cheddar cheese. J. Dairy Sci. 89:468-482.

Kefford, B., M. P. Christian, B. J. Sutherland, J. J. Mayes, and C. Grainger. 1995. Seasonal influences on cheddar cheese manufacture: Influence of diet quality and stage of lactation. J. Dairy Res. 62:529-537.

Kolver, E. S., J. R. Roche, C. R. Burke, J. K. Kay, and P. W. Aspin. 2007. Extending lactation in pasture-based dairy cows: I. Genotype and diet effect on milk and reproduction. J. Dairy Sci. 90:55185530 .

Lucey, J. 1996. Cheesemaking from grass based seasonal milk and problems associated with late lactation milk. J. Soc. Dairy Technol. 49:59-64.

Malcolm, B. 2005. Economics of extended lactations. Aust. Farm Bus. Mgt. Netwk. J. 2( 2).

O'Connell, J. E., and P. F. Fox. 2000. The two-stage coagulation of milk proteins in the minimum of the heat coagulation time-pH profile of milk: Effect of casein micelle size. J. Dairy Sci. 83:378386.

Standards Australia. 1988a. AS 2300.1.2.2. Methods of chemical and physical testing for the dairying industry - General methods and principles - Determination of nitrogen - Nitrogen fractions from milk. Standards Australia, Sydney, New South Wales, Australia.

Standards Australia. 1988b. AS 2300.1.3. Methods of chemical and physical testing for the dairying industry - General methods and 
principles - Determination of fat - Gravimetric method. Standards Australia, Sydney, New South Wales, Australia.

Standards Australia. 1988c. AS 2300.1.1. Methods of chemical and physical testing for the dairying industry - General methods and principles - Determination of total solids and moisture. Standards Australia, Sydney, New South Wales, Australia.

Standards Australia. 1988d. AS 2300.1.5. Methods of chemical and physical testing for the dairying industry - General methods and principles - Determination of ash. Standards Australia, Sydney, New South Wales, Australia.

Standards Australia. 1988e. AS 2300.2.9. Methods of chemical and physical testing for the dairying industry - Liquid milks Determination of phosphorus. Standards Australia, Sydney, New South Wales, Australia.

Standards Australia. 1988f. AS 2300.1.6. Methods of chemical and physical testing for the dairying industry - General methods and principles - Determination of $\mathrm{pH}$. Standards Australia, Sydney, New South Wales, Australia.

Standards Australia. 1991. AS 2300.1.2.1. Methods of chemical and physical testing for the dairying industry - General methods and principles - Determination of nitrogen - Reference Kjeldahl method. Standards Australia, Sydney, New South Wales, Australia.

Trapnell, L., and B. Malcolm. 2006. Economic analysis of changing from a 300 day lactation to an extended lactation system. Proc. Bienn. Conf. Australas. Farm Bus. Mgt. Netwk., Marcus Oldham College, Geelong, Victoria, Australia.

Webster, G. C. 1970. Comparison of direct spectrophotometric methods for the measurement of protein concentration. Biochim. Biophys. Acta 207:371-373.

White, J. C. D., and D. T. Davies. 1963. The determination of citric acid in milk and milk sera. J. Dairy Res. 30:171-189. 